$\begin{array}{rr}\text { JURNAL } & \text { Volume } 13 \text {, Nomor 4, Juli } 2017 \\ \text { FIT(1)PATOLOGI } & \text { Halaman } 136-144 \\ \text { I N DON O S I } & \text { DOI: } 10.14692 / \text { jfi.13.4.136 }\end{array}$

\title{
Keefektifan Perlakuan Fisik dan Minyak Atsiri untuk Mengeliminasi Bakteri Clavibacter michiganensis subsp. michiganensis pada Benih Tomat
}

\author{
The Effectiveness of Physical and Essential Oil Treatment to \\ Eliminate Clavibacter michiganensis subsp. michiganensis \\ on Tomato Seed
}

\author{
Siti Tri Wahyuni, Ali Nurmansyah, Giyanto* \\ Institut Pertanian Bogor, Bogor 16680
}

\begin{abstract}
ABSTRAK
Clavibacter michiganensis subsp. michiganensis merupakan bakteri penyebab penyakit kanker pada tomat. Bakteri ini bersifat tular benih dan dapat menyebabkan kehilangan hasil sampai $70 \%$. Perlakuan benih merupakan salah satu alternatif untuk mengendalikan penyakit ini. Tujuan penelitian ialah menentukan perlakuan fisik dan minyak atsiri yang efektif mengeliminasi $C$. michiganensis subsp. michiganensis dari benih tomat. Penelitian terdiri atas 4 percobaan, yaitu penapisan minyak atsiri, penentuan treatment window perlakuan, perlakuan fisik dan minyak atsiri pada benih tomat terinfeksi, dan kombinasi perlakuan fisik dan minyak atsiri pada benih tomat terinfeksi. Hasil penelitian menunjukkan bahwa minyak sirih mempunyai daya hambat paling besar $(27.33 \mathrm{~mm})$. Perlakuan air panas suhu $53{ }^{\circ} \mathrm{C}$ selama 25 menit pada benih terinfeksi mampu mengeliminasi $C$. michiganensis subsp. michiganensis dari benih tomat sebesar $90.94 \%$. Perlakuan panas kering pada suhu $60{ }^{\circ} \mathrm{C}$ selama 24 jam dan minyak sirih konsentrasi $0.25 \%$ dapat mengeliminasi C. michiganensis subsp. michiganensis berturut-turut sebesar $85.13 \%$ dan $99.82 \%$. Kombinasi perlakuan air panas suhu $55^{\circ} \mathrm{C}$, minyak sirih konsentrasi $0.5 \%$, dan panas kering suhu $60{ }^{\circ} \mathrm{C}$ mampu mengeliminasi bakteri C. michiganensis subsp. michiganensis sebesar $99.99 \%$ dengan persentase daya berkecambah mencapai $100 \%$. Perlakuan kombinasi ini dapat direkomendasikan untuk perlakuan benih tomat yang terinfeksi C. michiganensis subsp. michiganensis.
\end{abstract}

Kata Kunci: air panas, daya kecambah benih, minyak sirih, panas kering

\begin{abstract}
Clavibacter michiganensis subsp. michiganensis is the causal agent of bacterial canker disease of tomato. The bacteria is seed borne and may cause yield loss up to $70 \%$. Seed treatment is an alternative method for controlling bacterial canker. The objective of the research was to study the effectiveness of physical and essential oil treatment for elimination of C. michiganensis subsp. michiganensis from tomato seed. Research was conducted in 4 separate experiments, i.e. (1) screening essential oils to control C. michiganensis subsp. Michiganensis; (2) to determine the treatment window of physical and essential oil treatment; (3) to determine the physical and essential oil treatment on tomato seed infested by C. michiganensis subsp. Michiganensis; and (4) to determine the effectiveness of treatment combination of physical and essential oil. The results showed that betel oil at concentration of $8 \%$ had the greatest inhibitory level (approximately $27.33 \mathrm{~mm}$ ). Hot water treatment $\left(53^{\circ} \mathrm{C}\right)$ for 25 minutes reduced $90.94 \%$ of C. michiganensis subsp. michiganensis population; whereas dry heat treatment $\left(60{ }^{\circ} \mathrm{C}, 24\right.$
\end{abstract}

*Alamat penulis korespondensi: Departemen Proteksi Tanaman, Fakultas Pertanian, Institut Pertanian Bogor. Jalan Kamper, Kampus Darmaga IPB, Bogor 16680.

Tel: 0251-8629364, Faks: 0251-8629362; Surel: giyanto2@yahoo.com 
hours) and betel oil treatment at $0.25 \%$ concentration reduced $C$. michiganensis subsp. michiganensis population ( 85.13 and $99.82 \%$ respectively). The combination of betel oil $(0.5 \%)$, hot water $\left(55^{\circ} \mathrm{C}\right)$, and dry heat treatments $\left(60^{\circ} \mathrm{C}\right)$ was the most effective control method, because it reduced $99.99 \%$ of C. michiganensis subsp. michiganensis population and maintained the germination level of seed up to $100 \%$. This combination might be recommended for seed treatment to eliminate C. michiganensis subsp. michiganensis.

Key words: betel oil, dry heat, hot water, seed germination

\section{PENDAHULUAN}

Clavibacter michiganensis subsp. michiganensis merupakan bakteri tular benih penyebab penyakit kanker pada tanaman tomat. Bakteri ini menimbulkan kehilangan hasil hingga $20 \%$ di Canada, $20-30 \%$ di Perancis, dan 70\% di USA (Dhanvantari dan Brown 1993; EPPO 2013; CABI 2016). Menurut Peraturan Menteri Pertanian No.51/Permentan/ KR.010/9/2015, bakteri ini termasuk dalam organisme penganggu tumbuhan karantina (OPTK) kategori A2, dengan penyebaran masih terbatas di Provinsi Jawa Barat, Jawa Timur, Banten, Sumatera Barat dan Sumatera Selatan (Kementan 2015).

Pengendaliaan $C$. michiganensis subsp. michiganensis secara kimiawi menggunakan tembaga hidroksida yang diaplikasikan dengan mankozeb dan antibiotik streptomisin dilaporkan oleh Kasselaki et al. (2011) dan Werner et al. (2012). Akan tetapi, penggunaan antibiotik dapat menimbulkan resistensi pada patogen dan pencemaran lingkungan. Oleh karena itu, pengendalian alternatif perlu dikembangkan.

Minyak atsiri yang dapat digunakan mengendalikan bakteri patogen tanaman di antaranya ialah minyak cengkeh, minyak sirih, minyak pala dan minyak serai. Perendaman benih tomat dalam minyak cengkeh dengan konsentrasi $0.5 \%$ dapat mengeliminasi bakteri C. michiganensis subsp. michiganensis lebih dari $99 \%$ (Zainal et al. 2010). Minyak serai konsentrasi $1-2 \%$ dapat mengambat pertumbuhan bakteri Xanthomonas oryzae pv. oryzae secara in vitro (Rachmawati 2009). Ekstrak sirih dengan konsentrasi 2\% mampu menghambat pertumbuhan bakteri $X$. campestris pv. campestris sebesar $100 \%$ secara in vitro dan $99.9 \%$ pada benih kubis terinfeksi (Fitriawati 2012). Menurut Kusumaningrum et al. (2003), minyak pala dengan konsentrasi 1\% dapat menghambat pertumbuhan bakteri $X$. campestris dari tanaman brokoli secara in vitro.

Tujuan penelitian ialah menentukan keefektifan perlakuan fisik dan minyak nabati untuk mengeliminasi bakteri $C$. michiganensis subsp. michiganensis pada benih tomat tanpa merusak kualitas benih.

\section{BAHAN DAN METODE}

Benih tomat yang digunakan ialah varietas Tymoti $\mathrm{F} 1$ yang beredar di pasaran, C. michiganensis subsp. michiganensis merupakan koleksi Balai Besar Uji Standar Karantina Pertanian, Jakarta. Minyak atsiri yang digunakan adalah minyak atsiri komersial yang diproduksi oleh Balai Penelitian Tanaman Rempah dan Obat (Balittro), Bogor; yakni berasal dari tanaman sirih (Piper betle), cengkeh (Syzygium aromaticum), serai (Cymbopogon citratus), dan pala (Myristica fragrans).

\section{Penapisan Minyak Atsiri terhadap $C$. michiganesis subsp. michiganensis secara in vitro}

Bakteri C. michiganensis subsp. michiganensis diremajakan pada medium yeast dextrose calcium agar (YDCA). Pengayaan bakteri dilakukan dari satu koloni tunggal bakteri dan disuspensikan ke dalam $500 \mathrm{~mL}$ medium nutrient broth (NB). Suspensi bakteri pada medium NB kemudian diinkubasi di inkubator bergoyang dengan kecepatan 150 rpm selama 24 jam (Rahma 2013).

Penapisan daya hambat minyak atsiri dilakukan menggunakan metode difusi cakram. Minyak atsiri yang digunakan terdiri 
atas minyak cengkeh, minyak serai, minyak sirih, dan minyak pala dengan konsentrasi $0.125,0.25,0.5,1,2,4$, dan $8 \%$. Stok minyak atsiri dibuat dengan melarutkan minyak atsiri dalam air steril. Sebanyak $100 \mu \mathrm{L}$ suspensi bakteri C. michiganensis subsp. michiganensis disebar secara merata pada medium nutrient broth yeast agar (NBYA). Kertas whatman berdiameter $0.5 \mathrm{~cm}$ diletakkan di atas permukaan medium yang sudah diberi suspensi bakteri. Kertas whatman ditetesi $10 \mu \mathrm{L}$ minyak atsiri dan diinkubasi selama 48 jam. Sebagai kontrol negatif digunakan kertas whatman yang ditetesi air steril. Daya hambat minyak atsiri diamati dengan mengukur diameter zona bening di sekitar kertas whatman. Minyak atsiri yang mempunyai daya hambat paling baik digunakan untuk uji lanjut.

\section{Penentuan Treatment Window Perlakuan Benih}

Treatment window merupakan interval suhu atau dosis perlakuan untuk menghasilkan populasi patogen yang menurun, tetapi daya berkecambah benih tetap tinggi. Penentuan treatment window dilakukan pada bakteri C. michiganensis subsp. michiganensis dan benih tomat secara in vitro (Forsberg 2014). Perlakuan air panas diberikan dengan merendam benih dan tabung berisi suspensi bakteri $(\mathrm{OD}=0.2,600 \mathrm{~nm})$ setara dengan 3 $\times 10^{8} \mathrm{cfu} \mathrm{mL}^{-1}$ di dalam penangas air pada suhu 40, 45, 50, 51, 52, 53, 54, 55, dan 60 ${ }^{\circ} \mathrm{C}$ selama 25 menit. Perlakuan panas kering dilakukan dengan menempatkan benih dan tabung berisi suspensi bakteri $(\mathrm{OD}=0.2,600$ $\mathrm{nm}$ ) di dalam oven pada suhu 40, 45, 50, 60, dan $70{ }^{\circ} \mathrm{C}$ selama 24 jam. Perlakuan minyak sirih dilakukan dengan merendam benih dalam larutan minyak sirih pada konsentrasi 0.125 , $0.25,0.5,1,2,4$, dan $8 \%$ selama 25 menit.

Benih yang diberi perlakuan ditanam pada nampan plastik yang dilapisi tisu lembap. Pengamatan dilakukan terhadap vigor dan daya berkecambah benih. Suspensi bakteri yang diberi perlakuan diinkubasi di dalam inkubator bergoyang dengan kecepatan 150 rpm selama 24 jam. Kepadatan sel diukur berdasarkan nilai OD menggunakan spektrofotometer.
Data yang diperoleh dibuat grafik hubungan antara suhu atau konsentrasi perlakuan dengan daya berkecambah benih dan populasi bakteri. Interval suhu dan konsentrasi yang mampu menurunkan populasi bakteri dan mempertahankan daya kecambah benih yang tinggi (treatment window) digunakan untuk perlakuan selanjutnya.

\section{Perlakuan Fisik dan Minyak Atsiri pada Benih Terinfeksi $C$. michiganensis subsp. michiganensis}

Benih tomat diinokulasi $C$. michiganensis subsp. michiganensis secara buatan dengan merendamnya dalam suspensi bakteri $(O D=$ $0.2,600 \mathrm{~nm}$ ) selama 60 menit. Selanjutnya benih dikeringanginkan selama 24 jam.

Perlakuan air panas dilakukan dengan merendam benih terinfeksi di dalam penangas air pada suhu 50,53 , dan $55^{\circ} \mathrm{C}$ selama 25 menit. Perlakuan panas kering dilakukan dengan memasukkan benih tomat ke dalam oven pada suhu 60 dan $65^{\circ} \mathrm{C}$ selama 24 jam. Perlakuan minyak sirih dilakukan dengan merendam benih tomat di dalam larutan minyak sirih konsentrasi $0.125,0.25$, dan $0.5 \%$ selama 25 menit.

Benih tomat yang telah diberi perlakuan ditanam pada nampan plastik berisi medium tanam steril yang berisi campuran tanah dan pupuk kandang $(1: 1 \mathrm{v} / \mathrm{v})$. Peubah yang diamati ialah vigor dan daya berkecambah.

Pengaruh perlakuan terhadap populasi bakteri dilakukan dengan mengekstraksi benih tomat yang sudah diberi perlakuan dalam larutan $\mathrm{NaCl} \quad 0.8 \%$ dengan perbandingan 1:10. Sebanyak $100 \mu \mathrm{L}$ suspensi disebar pada medium NBYA kemudian diinkubasi selama 72 jam. Kepadatan populasi C. michiganensis subsp. michiganensis diamati dengan menghitung koloni yang tumbuh pada medium

Percobaan disusun dalam rancangan acak lengkap (RAL). Perlakuan minyak atsiri terdiri atas 3 konsentrasi: $0.125,0.25$, dan $0.5 \%$. Perlakuan air panas terdiri atas 3 suhu: 50, 53, dan $55^{\circ} \mathrm{C}$, sedangkan pengovenan terdiri atas 2 perlakuan, yaitu suhu 60 dan $65^{\circ} \mathrm{C}$. Masingmasing perlakuan diulang 3 kali. Data yang diperoleh dianalisis ragam menggunakan SAS 9.1.3 dan dilanjutkan uji Duncan pada $\alpha 5 \%$. 
Kombinasi Perlakuan Fisik dan Minyak Atsiri pada Benih Terinfeksi $C$. michiganensis subsp. michiganensis

Kombinasi perlakuan diberikan dengan merendam benih di dalam larutan minyak sirih konsentrasi $0.125,0.25$, dan $0.5 \%$ selama 25 menit di dalam gelas piala. Benih tersebut dipanaskan di dalam penangas air pada suhu 50 , 53, dan $55^{\circ} \mathrm{C}$. Benih kemudian di oven pada suhu 60 dan $65^{\circ} \mathrm{C}$ selama 24 jam.

Rancangan percobaan yang digunakan ialah split split plot dalam RAL dengan petak utama suhu panas kering, anak petak suhu air panas, dan anak anak petak konsentrasi minyak sirih. Masing-masing perlakuan diulang sebanyak 3 kali. Peubah yang diamati ialah viabilitas benih dan populasi bakteri. Data yang diperoleh dianalisis dengan analisis ragam menggunakan SAS 9.1.3 dan dilanjutkan uji Duncan pada $\alpha 5 \%$.

\section{HASIL}

\section{Daya Hambat Minyak Atsiri terhadap $C$. michiganensis subsp. michiganensis}

Pemberian minyak sirih dengan konsentrasi 8\% menghasilkan diameter zona bening paling lebar (Tabel 1). Oleh karena itu, minyak sirih digunakan untuk uji lanjut.

\section{Treatment Window Perlakuan Benih}

Perlakuan air panas pada suhu $50{ }^{\circ} \mathrm{C}$ dapat menurunkan populasi $C$. michiganensis subsp. michiganensis dan suhu $55{ }^{\circ} \mathrm{C}$ dapat mematikan bakteri ini. Perlakuan ini menghasilkan daya berkecambah benih tomat di atas $80 \%$ (Gambar 1a). Populasi bakteri $C$. michiganensis subsp. michiganensis menurun setelah perlakuan panas kering suhu $60^{\circ} \mathrm{C}$ dan tidak menurunkan daya berkecambah benih (Gambar 1b). Perlakuan panas kering suhu $70{ }^{\circ} \mathrm{C}$ dapat mematikan bakteri. Perlakuan minyak sirih dengan konsentrasi $8 \%$ dapat mengeliminasi populasi $C$. michiganensis subsp. michiganensis. Perlakuan minyak sirih dengan konsentrasi lebih dari $0.5 \%$ menyebabkan daya berkecambah di bawah $80 \%$. (Gambar 1c).

Berdasarkan treatment window, suhu perlakuan yang dapat digunakan untuk perlakuan benih tomat terinfeksi $C$. michiganensis subsp. michiganensis ialah 50,53 , dan $55^{\circ} \mathrm{C}$ untuk perlakuan air panas, suhu 60 dan $65^{\circ} \mathrm{C}$ untuk perlakuan panas kering, dan konsentrasi $0.125,0.25$, dan $0.5 \%$ untuk perlakuan minyak sirih (Gambar 1a, 1b, dan 1c).

\section{Perlakuan Fisik dan Minyak Atsiri pada Benih Terinfeksi $C$. michiganensis subsp. michiganensis}

Perlakuanairpanas yang direkomendasikan untuk perlakuan benih tomat ialah pada suhu $53{ }^{\circ} \mathrm{C}$ selama 25 menit. Perlakuan ini mengeliminasi bakteri hingga 90.94\% dengan daya berkecambah sebesar $86.67 \%$. Perlakuan panas kering yang paling baik ialah pada suhu $60{ }^{\circ} \mathrm{C}$ selama 24 jam dengan vigor dan daya berkecambah sama dengan perlakuan air panas

Tabel 1 Diameter zona bening dari aktivitas minyak atsiri terhadap bakteri Clavibacter michiganensis subsp. michiganensis secara in vitro

\begin{tabular}{lcccc}
\hline \multirow{2}{*}{$\begin{array}{c}\text { Konsentrasi } \\
(\%)\end{array}$} & \multicolumn{4}{c}{ Diameter zona bening $(\mathrm{mm})^{\mathrm{a}}$} \\
\cline { 2 - 5 } & Minyak cengkeh & Minyak sirih & Minyak serai & Minyak pala \\
\hline 0 & $0.00 \mathrm{i}$ & $0.00 \mathrm{i}$ & $0.00 \mathrm{i}$ & $0.00 \mathrm{i}$ \\
0.25 & $9.00 \mathrm{efg}$ & $7.00 \mathrm{fgh}$ & $6.33 \mathrm{gh}$ & $5.67 \mathrm{~h}$ \\
0.50 & $9.67 \mathrm{def}$ & $7.67 \mathrm{fgh}$ & $6.67 \mathrm{gh}$ & $6.33 \mathrm{gh}$ \\
1 & $11.33 \mathrm{de}$ & $7.67 \mathrm{fgh}$ & $7.00 \mathrm{fgh}$ & $7.00 \mathrm{fgh}$ \\
2 & $12.00 \mathrm{~d}$ & $15.67 \mathrm{c}$ & $7.33 \mathrm{fgh}$ & $7.33 \mathrm{fgh}$ \\
4 & $17.33 \mathrm{bc}$ & $19.67 \mathrm{~b}$ & $8.00 \mathrm{fgh}$ & $8.00 \mathrm{fgh}$ \\
8 & $19.33 \mathrm{~b}$ & $27.33 \mathrm{a}$ & $9.00 \mathrm{efg}$ & $10.67 \mathrm{de}$ \\
\hline
\end{tabular}

${ }^{a}$ Angka-angka pada kolom dan baris yang sama yang diikuti huruf yang sama tidak berbeda nyata menurut uji DMRT pada $\alpha 5 \%$ ) 


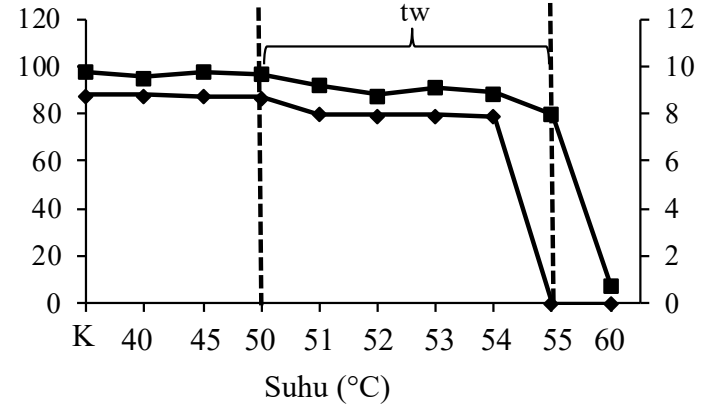

a

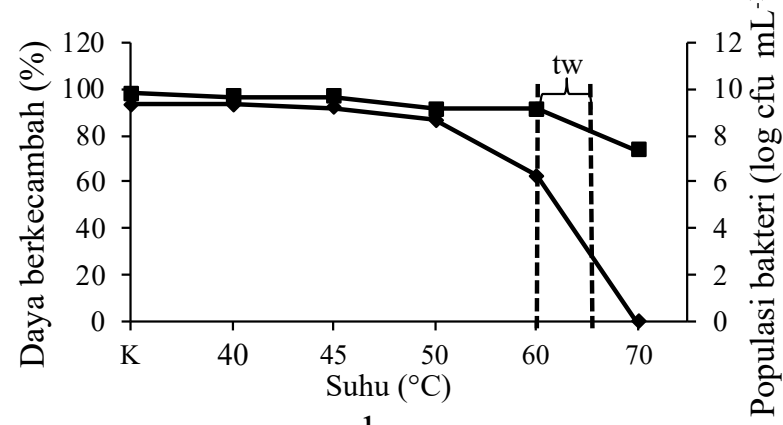

b

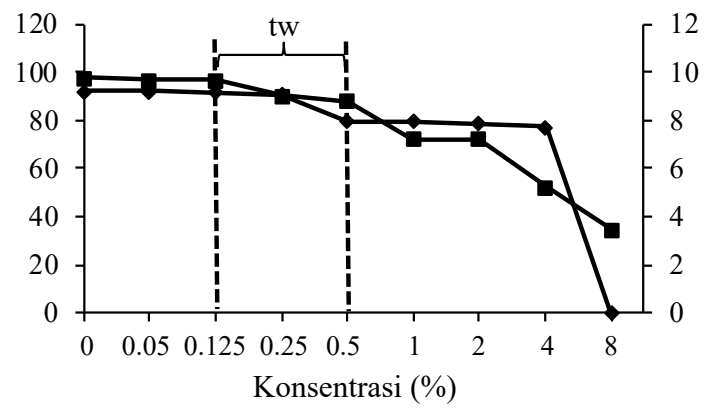

c

Gambar 1 Pengaruh perlakuan fisik dan minyak sirih terhadap daya berkecambah benih tomat dan populasi bakteri. a, air panas; $\mathrm{b}$, suhu kering; dan c, minyak sirih. tw, daerah treatment window. K, Kontrol; $\rightarrow$, Daya kecambah (\%); dan $\rightarrow$, Populasi bakteri (log cfu $\left.\mathrm{mL}^{-1}\right)$.

pada suhu $53{ }^{\circ} \mathrm{C}$. Pemberian minyak sirih konsentrasi $0.125,0.25$, dan $0.5 \%$ pada benih terinfeksi menghasilkan daya kecambah benih tomat yang sama dan persentase eliminasi bakteri di atas 99\% (Tabel 2).

\section{Kombinasi Perlakuan Fisik dan} Minyak Atsiri pada Benih Terinfeksi $C$. michiganensis subsp. michiganensis

Kombinasi perlakuan air panas suhu $55^{\circ} \mathrm{C}$, minyak sirih $0.5 \%$ selama 25 menit, dan panas kering pada suhu $60{ }^{\circ} \mathrm{C}$ selama 24 jam mampu mengeliminasi populasi bakteri paling tinggi dibandingkan dengan perlakuan yang lain. Kombinasi tersebut menghasilkan daya berkecambah benih hingga 100\% (Tabel 3).

\section{PEMBAHASAN}

Minyak sirih mempunyai daya hambat paling besar terhadap $C$. michiganensis subsp. michiganensis dibandingkan dengan minyak cengkeh, minyak serai, dan minyak pala. Keefektifan minyak sirih dalam menghambat bakteri disebabkan kandungan senyawa flavonoid, tanin, dan minyak atsiri. Flavonoid mempunyai sifat sebagai koagulator protein, mengganggu integritas sel bakteri dengan membentuk senyawa kompleks pada permukaan sel bakteri. Minyak atsiri sirih mengandung senyawa kavikol, allipirokatekol, kavibetol, metil kavikol, metil eugenol, 1.8-sineol, eugenol, kariofilena, dan kadinena (Suppakul et al. 2006). Senyawa-senyawa tersebut bersifat hidrofobik dan menyebabkan peningkatan permeabilitas membran sel bakteri sehingga sel bakteri akan mengalami kerusakan. Ekstrak sirih konsentrasi 2\% mampu mematikan $X$. campestris pv.campestris sebesar $100 \%$ secara in vitro dan $99.9 \%$ pada benih kubis terinfeksi (Fitriawati 2012).

Perlakuan air panas suhu $53{ }^{\circ} \mathrm{C}$ selama 25 menit dapat direkomendasikan untuk perlakuan benih tomat karena perlakuan ini dapat menurunkan populasi bakteri dengan daya berkecambahnya di atas $80 \%$. Secara umum pengaruh panas terhadap bakteri patogen meliputi perubahan dalam struktur dinding dan inti sel, denaturasi protein, kerusakan mitokondria, gangguan pada membran vakuola, sitoplasma, keluarnya senyawa lipid, kerusakan hormon, berkurangnya oksigen pada jaringan, dan gangguan metabolisme di dalam sel bakteri (Nega et al. 2003). Perlakuan air panas suhu $55{ }^{\circ} \mathrm{C}$ selama 25 menit menyebabkan daya berkecambah benih rendah. Air panas suhu tersebut tidak mampu mematahkan dormansi benih, tetapi menyebabkan kerusakan benih khususnya bagian embrio sehingga menurunkan perkecambahan benih. Perlakuan air panas 
Tabel 2 Vigor, daya berkecambah benih, dan populasi bakteri Clavibacter michiganensis subsp. michiganensis pada berbagai taraf suhu air panas, panas kering, dan konsentrasi minyak sirih

\begin{tabular}{|c|c|c|c|c|}
\hline Perlakuan & $\begin{array}{l}\text { Vigor benih } \\
(\%)^{\mathrm{a}}\end{array}$ & $\begin{array}{l}\text { Daya berkecambah } \\
(\%)^{\mathrm{a}}\end{array}$ & $\begin{array}{c}\text { Populasi bakteri } \\
\left(\log 10 \mathrm{cfu} \mathrm{g}^{-1} \text { benih }\right)^{\mathrm{a}}\end{array}$ & $\begin{array}{l}\text { Persentase } \\
\text { eliminasi }^{\mathrm{b}}\end{array}$ \\
\hline \multicolumn{5}{|c|}{ Air Panas } \\
\hline Kontrol & $61.11 \mathrm{~b}$ & $71.11 \mathrm{ab}$ & $6.59 \mathrm{a}$ & 0.00 \\
\hline $50{ }^{\circ} \mathrm{C}$ & $81.11 \mathrm{a}$ & $82.22 \mathrm{a}$ & $5.86 \mathrm{~b}$ & 81.20 \\
\hline $53^{\circ} \mathrm{C}$ & $80.00 \mathrm{a}$ & $86.67 \mathrm{a}$ & $5.55 \mathrm{c}$ & 90.94 \\
\hline \multicolumn{5}{|c|}{ Panas Kering } \\
\hline $60{ }^{\circ} \mathrm{C}$ & $68.89 \mathrm{a}$ & $81.11 \mathrm{a}$ & $5.81 \mathrm{~b}$ & 85.13 \\
\hline $65^{\circ} \mathrm{C}$ & $57.78 \mathrm{a}$ & $\begin{array}{l}67.78 \mathrm{a} \\
\quad \text { Minyak Si }\end{array}$ & $5.42 \mathrm{c}$ & 94.23 \\
\hline $0.125 \%$ & $93.33 \mathrm{a}$ & $94.45 \mathrm{a}$ & $4.16 \mathrm{~b}$ & 99.63 \\
\hline $0.25 \%$ & $91.11 \mathrm{a}$ & $92.22 \mathrm{a}$ & $3.82 \mathrm{c}$ & 99.82 \\
\hline $0.50 \%$ & $75.55 \mathrm{ab}$ & $80.00 \mathrm{a}$ & $3.76 \mathrm{c}$ & 99.84 \\
\hline \multicolumn{5}{|c|}{ yang diikuti huruf yang sama menunjukan tidak berbeda nya } \\
\hline
\end{tabular}

suhu $50^{\circ} \mathrm{C}$ selama 60 menit dapat mengurangi populasi bakteri $X$. campestris pv. carotae pada benih wortel dan mampu mengeliminasi populasi bakteri tersebut pada suhu $53{ }^{\circ} \mathrm{C}$ selama 10 menit (Nega et al. 2003). Panas kering merusak struktur dinding sel bakteri dan menyebabkan terjadinya denaturasi dan agregasi protein sehingga bakteri menjadi inaktif (Kubota et al. 2012). Perlakuan panas kering pada suhu $60{ }^{\circ} \mathrm{C}$ selama 24 jam juga dapat mematikan bakteri $P$. stewartii subsp. stewartii sebesar $100 \%$ secara in vitro (Nalis et al. 2015).

Peningkatan vigor dan daya berkecambah benih tomat setelah perlakuan minyak sirih disebabkan minyak sirih menekan populasi bakteri $C$. michiganensis subsp. michiganensis. Pemberian perlakuan minyak sirih dapat menekan populasi bakteri $C$. michiganensis subsp. michiganensis pada benih tomat terinfeksi, menaikkan vigor, dan daya berkecambah benih tomat. Hal ini sesuai dengan hasil penelitian dari Zainal et al (2010), yaitu ekstrak daun sirih dapat mengeliminasi bakteri C. michiganensis subsp. michiganensis dan menghasilkan perkecambahan benih, laju perkecambahan, dan keseragaman tumbuh yang tinggi setelah benih diberi perlakuan.

Kombinasi perlakuan air panas suhu $55^{\circ} \mathrm{C}$, minyak sirih konsentrasi $0.5 \%$ selama 25 menit dan panas kering dengan suhu $60{ }^{\circ} \mathrm{C}$ selama 24 jam efektif mengeliminasi populasi bakteri C. michiganensis subsp. michiganensis pada benih tomat dibandingkan dengan perlakuan yang dilakukan secara sendiri-sendiri. Oleh karena itu, kombinasi ini dapat digunakan sebagai salah satu alternatif mengileminasi C. michiganensis subsp. michiganensis pada benih tomat. Perlakuan panas kering selain bertujuan mengeliminasi populasi $C$. michiganensis subsp. michiganensis, juga mengeringkan benih agar lebih lama disimpan.

Pengaruh perlakuan panas kering setelah perlakuan minyak sirih dan air panas meningkatkan daya berkecambah benih tomat. Hasil penelitian Farooq et al. (2006), pemberian panas kering suhu $50^{\circ} \mathrm{C}$ dan $60{ }^{\circ} \mathrm{C}$ selama 24 jam pada benih tomat mampu meningkatkan daya berkecambah dan vigor dibandingkan dengan yang tidak diberi perlakuan.

Perlakuan yang paling efektif untuk mengendalikan bakteri $C$. michiganensis subsp. michiganensis pada benih tomat ialah 
- $8 \hat{\alpha}$ กิ ஓ î ळ

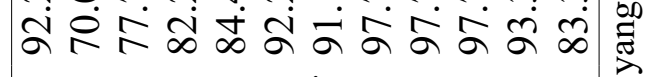
बं

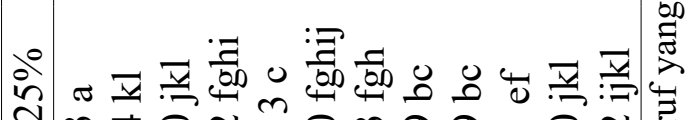
ㄱำ $m 8$ 응 - 
kombinasi perlakuan minyak sirih dengan konsentrasi $0.5 \%$, air panas pada suhu $55^{\circ} \mathrm{C}$ selama 25 menit, dilanjutkan panas kering pada suhu $60{ }^{\circ} \mathrm{C}$ selama 24 jam. Kombinasi perlakuan ini hampir memusnahkan populasi bakteri C. michiganensis subsp. michiganensis dan mempertahankan daya berkecambah benih mencapai $100 \%$.

\section{DAFTAR PUSTAKA}

[CABI] Centre in Agricultural and Biologcal Instiute. 2016. Datasheet: Clavibacter michiganensis subsp. michiganensis (bacterial canker tomato). http://www. cabi.org/isc/datasheet/15338. [diakses 22 Maret 2016].

Dhanvantari BN, Brown RJ. 1993. Improved seed treatments for control of bacterial canker of tomato. Can J Plant Pathol. 15(3):201-205. DOI:https://doi. org/10.1080/07060669309500823.

[EPPO] European and Mediterranian Plant Protection Organization. 2013. Data Sheets on quarantine pests Clavibacter michiganensis subsp. michiganensis. https://www.eppo.int/QUARANTINE/ data_sheets/bacteria.[ diakses 2016 Mei 25].

Farooq M, Basra SMA, Salem BA, Nafees M. 2008. Germination, seedling vigor and electrical conductivity of seed leachates as affected by dry heat treatment of tomato seeds. Acta Horti. 771:4350. DOI:http://dx.doi.org/ 10.17660/ ActaHortic.2008.771.5.

Fitriawati N. 2012. Keefektifan ekstrak empat jenis tumbuhan dan kitosan terhadap bakteri Xanthomonas campestris pv. campestris penyebab penyakit busuk hitam pada kubis [Tesis]. Bogor (ID): Institut Pertanian Bogor.

Forsberg G. 2001. Heat sanitation of cereal seeds with a new, efficient, cheap and environmentally friendly method. Di dalam: Proceedings of Symposium no. 76 of the British Crop Protection Council: Seed Treatment, Challenges and Opportunities. Farnham (UK): BCPC. Hlm. 69-72.
Kasselaki AM, Goumas D, Tamm L, Fuchs J, Cooper J, Leifert C. 2011. Effect of alternative strategies for the disinfestion of tomato seed infected with bacterial canker (Clavibacter michiganensis subsp. michiganensis). J Life Sci. 58(2011):145147. DOI:10.1016/j.nj12.2011.07.001.

[Kementan] Kementerian Pertanian. 2015. Peraturan Menteri Pertanian Nomor 51/ Permentan/KR.010/9/2015 tentang Jenis Organisme Pengganggu Tumbuhan Karantina. Jakarta (ID): Kementan.

Kubota M, Hagiwara N, Shirakawa T. 2012. Disinfection of seeds of cucurbit crops infested with Acidovorax citrulli with dry heat treatment. J Phytopathol. 12:15. DOI: https://doi.org/10.1111/j.14390434.2012.01913.x.

Nalis S, Suastika G, Giyanto. 2015. Perlakuan panas kering dan bakterisida untuk menekan infeksi Pantoea stewartii subsp. stewartii pada benih jagung manis. J Fitopatol Indones. 11(4): 128-135. DOI: 10.14692/jfi.11.4.128.

Nega E, Ulrich R, Welner S, Jahn M. 2003. Hot water treatment of vegetable seed, an alternative seed treatment method to control seedborne pathogens in organik farming. J Plant Dis Prot. 110(3):220-234.

Rahma H. 2013. Kajian penyakit layu stewart pada jagung yang disebabkan oleh Pantoea stewartii subsp. stewartii dan pengendaliannya [disertasi]. Bogor (ID): Institut Pertanian Bogor.

Rachmawati AY. 2009. Pengaruh perlakuan matriconditioning plus bakterisida sintetis atau nabati untuk mengendalikan hawar daun bakteri (Xanthomonas oryzae pv. oryzae) terbawa benih serta meningkatkan viabilitas dan vigor benih padi (Oryza sativa) [skripsi]. Bogor (ID): Institut Pertanian Bogor.

Sen Y, Wolf JVD, Visser RGF, Van Heusden S. 2015. Bacterial canker of tomato: current knowledge of detection, management, resistance, and interations. Plant Dis. 99(1): 4-13. DOI: https://doi.org/10.1094/ PDIS-05-14-0499-FE. 
Suppakul P, Sanlaead N, Phoopuritham P. 2006. Zainal Abidin, Anwar A, Ilyas S, Giyanto. Antimicrobial and antioxidant activity 2010. Efektifitas ekstrak tumbuhan untuk of betel oil. Kasetsart J. 40(1):91-100. mengeliminasi Clavibacter michiganensis Werner NA, Fulbrigt DW, Podolsky R, Bell J, Hausbeck MK. 2012. Limiting populations subsp. michiganensis pada benih tomat. J and spread of Clavibacter michiganensis Agron Indones. 38(1):52-59.

subsp. michiganensis on seedling tomatoes in the greenhouse. Plant Dis: 85(5):535-542. 